\title{
CAN INDONESIA INVOKE PUBLIC MORALS EXCEPTION UNDER THE WORLD TRADE ORGANIZATION (WTO) FOR PROHIBITING CROSS- BORDER GAMBLING?
}

\author{
I Gusti Ngurah Parikesit Widiatedja \\ Faculty of Law, Udayana University \\ E-mail : ngurahparikesit@gmail.com
}

\begin{abstract}
Under the World Trade Organization (WTO), Indonesia is obliged to liberalize its markets through establishing the schedule that comprise a list of services that can be either opened or closed to foreign suppliers. However, Indonesia's schedule is vague as to whether gambling services are closed to foreign suppliers. Through this loophole, the practice of cross-border gambling services has been rampant, resulting in some consequences, especially those related to money laundering and underage gambling. Tackling this problem, Indonesia could apply public morals exception that allows member states to impose trade prohibition. By using public morals exception that was applied in some WTO cases, this article explores the way in which Indonesia could justify prohibiting cross-border gambling services. This articles claims that Indonesia has a justification to impose public morals exception under the WTO to prohibit cross-border gambling services within its territory because the prohibition would be designed to protect public morals; it would be necessary to protect public morals; and the prohibition would equally apply to both foreign and local suppliers in cross-border gambling services in Indonesia.
\end{abstract}

Keywords: Public Morals, Exception, World Trade Organization, Cross-Border Gambling.

\section{A. INTRODUCTION}

The World Trade Organization (WTO) has covered not only trade in goods but also trade in services. In services, all members established General Agreement on Trade in Services (GATS) that obligated each member of WTO to launch the schedule that comprised a list of services that could be either opened or closed to foreign suppliers. After the establishment of the GATS, cross-border gambling services rapidly increased. These services include arrangements in which, suppliers from the territory of one member state can provide gambling to the territory of another member state via the Internet (Article 1 of the GATS, 1994). In August of 1995, six months after GATS was entered into force, the first online casino was launched, five years later, 250 to 300 companies ran more than 1,800 gambling websites (US. Gen. Accounting Office, 2002: 3). No business that uses the Internet generates as much revenue as online gambling (John D. Andrle, 2004: 1391). 
Despite generating huge revenue for providers, cross-border gambling is an essentially borderless activity that creates complications related to regulation and enforcement procedures. Currently, there are over 50 global jurisdictions that either regulate or tolerate these services based on their schedules under the GATS (Joel Weinberg, 2006: 293). Indonesia's schedule is vague as to whether gambling services are closed to foreign suppliers (Indonesia's GATS Schedule, 1994). Through this loophole, the practice of cross-border gambling services has been rampant, resulting in some consequences, especially those related to money laundering and underage gambling.

Cross-border gambling are the most susceptible services to money laundering because of their characteristics and methods of payment. The anonymous nature of the Internet, huge amounts of cash, and the difficulty to catch online gambling owner are the reason cross-border gambling becomes a place for money laundering (LD Moodie, 2002: 18). As regards to method of the payment, e-cash payment that based on encryption technologies can make all transactions completely anonymous and untraceable even to its issuer (Joel Weinberg, 2006: 298). There are several cases of money laundering that derived from online gambling activities in Indonesia. The Financial Transaction Reports and Analysis Centre (PPATK) has blocked 119 accounts held at four banks, whose funds are allegedly linked to online gambling activities. All of the blocked accounts have used new payment methods (NPMs) for money laundering including e-cash. From the investigation of PPATK, there were 14 NPM cases using e-cash derived from fraud and online gambling. Most NPMs are conducted in Jakarta (35.71 percent), followed by East Java (28.7 percent) and West Java (21.43 percent) (Kompas, 2014).

The existence of cross-border gambling services in Indonesia is not only attractive for mature people but also for children and teenagers. It is because this business provides user-friendly features, unlimited time of operation, and lack of age verification. Children and teenager can easily play online gambling and they just simply sign up, and if they do not have their own account, they can use their friend's account (Riau Post, 2014). They usually use older people account to bet seriously in that game (Kompas, 2013). Besides, a complete video guidance how to gamble can be found in many online gambling website or they can use search engine website to explain how to effectively gamble. 
As regards to unlimited time of operation, minors can easily access internet gambling websites that are readily available for all hours of the day or night. This situation can make them playing gamble uninterrupted and undetected for unlimited periods of time. Moreover, some social media provides online gambling that can increase the opportunity for minors to repeatedly gamble (Elga Andina, 2010: 124). With respect to the lack of age verification, some online gambling websites do not verify the age of their users referring to the anonymity principle. Unlike online gambling, in traditional physical gambling, the operators can look their customers to assess their age, and request photo identification (LaPlante, 2009: 719).

From international trade law perspective, tackling this problem, Indonesia could apply public morals exception under the WTO that is regulated in Article XX GATT or Article XIV GATS. This provision allows member states to impose trade prohibition if it is necessary to protect public morals. By using this exception, the author explores the way in which Indonesia could justify in prohibiting cross-border gambling services to protect public morals. This paper begins by examining the provisions from the WTO that allow member states to impose trade prohibitions based on public morals, and how the judicial body considered public morals in the judgment of the WTO cases. Then, it explains how public morals exception, specifically the decision from the WTO judicial body could be applied to justify Indonesian law that would prohibit cross-border gambling to protect public morals. Finally, this paper concludes by showing that Indonesia has a justification under the WTO to prohibit cross-border gambling services within its territory.

\section{B. PROBLEM STATEMENT}

In accordance with the above-mentioned theme, this article analyses whether Indonesia can successfully invoke public morals exception under the WTO for prohibiting cross-border gambling within its territory.

\section{RESEARCH METHODS}

This research will apply a normative approach by analyzing relevant international conventions, laws and other legal documents, as well as the results of research, assessment, and other references related to World Trade Organization. This research is also complemented by a 
comparative study to examine practices with respect to public morals exception under the World Trade Organization (wto) and policies that are implemented at regional and international levels.

\section{DISCUSSION AND RESULT}

\section{Public Morals Exception Under The World Trade Organization}

Public morals are regulated under Article XX GATT and Article XIV GATS that allows the member to impose trade restrictions if it is necessary to protect public morals. Regarding the connection between those two articles, the Appellate Body in EC-Banana III confirmed that jurisprudence under the Article XX GATT could be relevant for the interpretation of article XIV GATS (EC - Banana III Case, 1997). Article 3.2 Dispute Settlement Understanding (DSU) clarifies that the panels and the Appellate Body must "clarify the existing provisions of those agreements by customary rules of interpretation of the public international law" (Article 3.2 the DSU, 1994). In the US - Gasoline, the Appellate Body has plainly indicated that "the general rule of interpretation" in the Article 31 of the Vienna Convention on the Law of Treaties (VCLT), has reached the position of a rule of customary or general international law (US - Gasoline Case, 1996).

Article 31 Vienna Convention comprehensively provides the rule of treaty interpretation. Good faith is the main principle to interpret a treaty by the ordinary meaning of treaty's term referring its context and in the light of its object and purpose (Article 31 of Vienna Convention, 1969). In EC - Customs Classification of Chicken Cuts, the Appellate Body stated that dictionaries were a useful starting point to analyze the ordinary meaning of a treaty term, but they are not necessarily dispositive (EC - Chicken Cuts Case, 2005).

The Vienna Convention also launches direction for supplementary interpretation, mentioning that recourse may be had to supplementary means of interpretation, including the preparatory work and the circumstances of its inclusion, especially if the plain interpretation makes ambiguity (Article 32 Vienna Convention, 1969). In EC - Custom Classification of Chicken Cuts, the Appellate Body decided that the relevance of a circumstance for interpretation should be determined on the ground of objective factors, and not the subjective intent. These factors include the type of event, document, or instruments and its legal nature; the temporal relation of the circumstance to the conclusion 
of the treaty; actual knowledge or mere access to a published act or instrument; and subject matter of the document, instrument (EC - Chicken Cuts Case, 2005).

For almost 70 years, there was no exact interpretation of public morals. From a historical perspective, In November 1945, the United States initiated the idea of permitting countries to impose trade restrictions on the moral ground that took place during the early phases of the legal drafting of the GATT founding agreements (Mark Wu, 2008: 217). The US's proposal was aimed to protect a series of trade restrictions that the US and other countries already had in place at the time the GATT was negotiated, including "intoxicating liquors, smoking opium and narcotic drugs, lottery tickets, obscene and immoral articles, counterfeits, pictorial representations of prize fights, and the plumage of certain birds". In this negotiation process, the definition of public morals was not a primary concern as there was no intensive discussion to explain what actually constituted public morals (Steve Charnovitz, 1998: 706). Therefore, the GATT agreement simply kept the earlier drafts' language that members can impose measures necessary to protect public morals, without providing any further explanatory text (United Nations Conference on Trade and Employment, 1948).

Although there is no strong basis for the interpretation of public morals, members have imposed trade restrictions that they argued were in the interest of public morals. Specifically, Canada expressly stated its prohibition for child pornography and materials deemed obscene, treasonous, or seditious. Colombia prohibits pornographic material involving minors. Similarly, South Korea and Mozambique prohibit pornographic materials although did not expressly stated what specific type of pornography was.

Some WTO cases tried to interpret what constituted public morals. In US Gambling, the Panel defined public morals as: (US - Gambling Case, 2004).

"The term 'public morals' denotes standards of right and wrong conduct maintained by or on behalf of a community or nation... The content of these concepts for Members can vary in time and space, depending upon a range of factors, including prevailing social, cultural, ethical and religious values... Members should be given some scope to define and apply for themselves the 
concepts of 'public morals' in their respective territories, according to their systems and scales of values."

\section{The Application of Public Morals Exception Under the WTO Cases}

Under the WTO, a measure that conflicts with GATT and GATS provisions can be construed as a trade restriction or a trade prohibition (Article XI GATT, 1994). Article XX GATT is distinguished into two parts: (1) The specific exception listed in paragraphs (a) to (j); and (2) The introductory paragraph (called the "chapeau") (Article XX GATT, 1994). To be eligible for an exception, it is necessary to satisfy both specific exception and the introductory paragraph. In US - Gasoline, the panel established following elements that had to be satisfied for granting an exception (US - Gasoline Case, 1996):

1. That the policy in related to the measures for which the provision was invoked fell within the range of policies designed to pursue specific exception;

2. That the inconsistent measures for which the exception was being invoked were necessary to fulfill the policy objective; and

3. That the measures were applied in conformity with the requirement of the introductory clause of article XX GATT.

\section{a. Trade Measure Must Be Designed to Pursue Specific Exception}

The next elements for granting an exception is that the measure must be designed to protect the specific exception listed in paragraph (a) to (j) Article XX GATT and Article XIV GATS consisting: public morals; human, animal or plant life or health; secure compliance with laws and regulations; and the conservation of exhaustible natural resources.

In EC - Asbestos, the Appellate Body determined that "the protection of human, animal and plant life or health" mentioned in Article XX (b) GATT, applied to French Regulation that banned asbestos fiber in any form because they pose a high risk of human health, especially lung cancer, and mesothelioma (EC - Asbestos Case, 2001). Hence, the goal of this prohibition was to protect human health.

In the US - Gambling, Antigua brought suit against the US under Article XVI of GATS because the U.S. prohibited cross-border gambling and betting services. The US argued that the prohibition on remote gambling was necessary to protect public morals. 
Specifically, remote gambling has increased the threatfor: (1) Organized crime, (2) Money laundering, (3) Fraud and other consumer crimes, (4) Public health (i.e., pathological gambling), and (5) Children and youth or underage gambling. Both panel and the Appellate Body agreed that maintaining a society in which people and their property exist free of the harmful influence of organized crime, fraud, and underage gambling was a matter of public morals (US - Gambling Case, 2004).

In China - Audiovisual, China introduced trade restrictions on the importation and distribution of certain products, consisting of reading materials, audio-visual products, sound recordings, and films for theatrical release as they had been classified as "cultural products." The reason for this measure was because these products may have a potentially negative impact on the public morals. Both panel and the Appellate Body acknowledged that these restrictions were within the scope of public morals in China (China Audiovisual Case, 2009).

In EC - Seal Products, The EU prohibited the importation and marketing of seal products (EU Seal Regime) to address the EU's moral concerns about the welfare of seals. This measure was harshly contested by Canada where sealing was a vital cultural practice for its indigenous Inuit communities, as well as by Norway. Both panel and the Appellate Body found that this prohibition was to "address the moral concerns of the EU public about the welfare of seals," and that addressing public concerns about seal welfare is a "legitimate" objective within the meaning of the public morals exception (EC - Seal Products Case, 2014).

\section{b. Trade Measure Must Be Necessary to Pursue Specific Exception}

In Korea- Beef, Korea launched dual retail system for beef that separated domestic and imported beef. This measure was to embattle fraudulent practices conflicted with Korea's Unfair Competition Act. The Appellate Body stated that the analysis to determine a measure was "necessary" involved a weighing and balancing of facts including the following: (Korea - Beef Case, 2000).

(1) The contribution of the measure to the ends pursued, meaning that the greater the contribution, the more easily a measure might be classified as "necessary"; 
(2) The importance of the common interest or value protected, meaning that the more vital or important those common interests or values are, the easier it would be satisfied as "necessary" a measure; and

(3) The impact of the measure on import or exports. In other words, a measure with a relatively minor impact upon imported products might more easily be categorized as "necessary" than a measure with strong or wider restrictive impact.

In its analysis, the Appellate Body stated that the protection from fraudulent practices in beef products could be managed without using the dual retail system. Furthermore, the absence of dual retail systems in other sectors of the Korean economy reflected that the common interest was not vital or important. Moreover, the dual retail systems had significant trade effects for Australia and the U.S. as major suppliers of beef products. For these reasons, the Appellate Body found that the dual retail system was a measure that was not necessary to secure compliance with the Korean law against deceptive practices, and then it was not justified by Article XX (d) of GATT (Korea - Beef Case, 2000).

In EC - Asbestos, the Appellate Body stated that once a preliminary conclusion that a measure was necessary has been satisfied, it must be compared with the "reasonably available alternative measure" beside trade restriction or prohibition. Satisfying with the elements of necessary, then the Appellate Body examined "reasonably available alternative measure" that was provided by Canada. Instead of prohibiting asbestos fibers, Canada provided "controlled use" to halt the spread of asbestos-related health risks. However, the Appellate Body stated that the effectiveness of "controlled use" was particularly doubtful for the building industry according to scientific evidence. Hence, "controlled use" would not allow France to reach its chosen level of health protection by stopping the spread of asbestos-related to health risk. For these reasons, the Appellate Body was satisfied that there was no "reasonably available alternative measure" beside prohibition (EC - Asbestos Case, 2001).

In the US - Gambling, analyzing the importance of interest or value that was protected by the measure, the Panel checked congressional statements and legislative history from the Wire Act, Travel Act, and IGBA. The Panel found that three acts were intended to protect society against the threat of money laundering, organized crime, fraud, 
and risks to children. Hence, the Panel was satisfied because the measures served societal interest that was vital and important in the highest degree (US - Gambling Case, 2004).

In the second part, analyzing that three federal statutes contributed to the realization of the ends pursued, the Panel examined a sufficient "nexus" between the remote supply of gambling and concernsrelating to money laundering, organized crime, fraud, underage gambling, and pathological gambling. The Panel deemed that these acts must contribute, at least to some extent, to addressing these concerns. Therefore, the Panel was unanimously satisfied by the inherent prohibitions from three federal statutes that had a satisfactory "nexus" with money laundering, organized crime, and underage gambling (US - Gambling Case, 2004).

Concerning the trade impact, the Panel recognized that of the effect of these laws was total prohibitions that had a significant restrictive trade impact. Nonetheless, the Panel admitted that a member has the right to restrict a highly risky service that was online gambling, while permitting the use of less risky service that was physical traditional gambling. In particular, the Panel found specific damages related to online gambling including (a) The volume, speed, and international reach of its transactions; (b) The virtual anonymity of transactions; (c) Low barriers to entry these services; and (d) Isolated and anonymous environment in which such gambling exist (US - Gambling Case, 2004).

From three balancing factors test, the Panel found a preliminary conclusion that the measures were "necessary" to protect public morals. Then, the Panel examined whether the U.S. had explored and exhausted all "reasonably available alternative measure" before adopting those prohibitions, referred to EC - Asbestos case. The Panel held that the U.S. had a "reasonably available alternative measure" before prohibiting cross-border gambling. In this context, the U.S. had an obligation to consult with Antigua before imposing its prohibitions on cross-border gambling. However, the Panel found that the U.S. had not engaged in such consultation and rejected Antigua's invitation for conducting consultation so that the U.S. had failed to provisionally justify that its prohibitions were "necessary to protect public morals" (US - Gambling Case, 2004). 
Interestingly, the Appellate Body created new assessments to determine what constituted reasonably available alternative measures. It identified three factors surprising: (US - Gambling Case, 2004).

(a) An alternative measure must be less trade restrictive than the measure at issue;

(b) An alternative must preserve the right of the U.S. to achieve its desired level of protection from the harmful effects of cross-border gambling; and

(c) An alternative measure must be reasonably available, meaning it must create the U.S. capable of undertaking (not just theoretical in nature), and it must not be unduly burdensome such as prohibitive costs or substantial technical difficulties.

From those considerations, a preliminary conclusion that the measures were "necessary to protect public morals" has been reached by the U.S. Moreover, Antigua failed to identify a "reasonably available alternative measure" for the U.S. so that the prohibitions were measures "necessary to protect public morals" (US - Gambling Case, 2004).

In EC - Seal Products, the Panel determined that the EU was eligible under Article 2.2 of the TBT Agreement to prohibit the importation and marketing of seal products because it was aimed at, and made some contribution toward, addressing the EU public moral concerns over animal welfare. Moreover, it determined that alternative and less restrictive measures (i.e. labelling seal products harvested through a humane hunt) were not reasonably available given the challenges associated with the establishment of appropriate standards and any subsequent implementation and monitoring of such a program. Hence, the EU's prohibition on the importation and marketing of seal products could be justified as “necessary to protect public morals" (EC - Seal Products Case, 2014).

\section{c. Trade Measure Must Comply with the Non-discriminatory Principle}

Beside the measure must satisfy one of the specific exceptions listed in paragraph (a) to (j) Article XX GATT and Article XIV GATS, it must also satisfy the article XX "chapeau." Trade measures must not be applied to constitute "arbitrary or unjustifiable discrimination" between countries where the same conditions prevail, or a "disguised restriction on international trade" (Article XX GATT, 1994). 
In US - Shrimp, the U.S. issued regulation under Endangered Species Act stipulated U.S. shrimp trawlers to use "turtle excluder devices" (TEDs) that allowed shrimp to pass through to the back of the net while preventing turtle or other large animals from doing so. Although this measure was necessary to "the conservation exhaustible natural resources," the Appellate Body stated that a measure was "unjustifiable discrimination." It was because this measure required other WTO members to adopt essentially the same policies and enforcement practices as the U.S. without considering their different conditions which may occur in the territory of those other members. Furthermore, the U.S. did not undertake comparable negotiations with all relevant exporting countries before imposing its measure (US - Shrimp Case, 1998).

In US-Gambling, the Panel examined the scope of implementation of the Interstate Horseracing Act (IHA). It was because the text of the IHA stated that "[a]n interstate offtrack wager may be accepted by an off-track betting system" where consent is obtained from certain organizations. In the other words, Panel found that the IHA allowed domestic service suppliers, but not Foreign Service suppliers, to offer remote betting services in relation to certain horse races. To this extent, the IHA exempted domestic service suppliers from the prohibitions of the Wire Act, the Travel Act, and the IGBA (US - Gambling Case, 2004).

The Appellate Body agreed with the Panel's finding that the prohibitions in the International Horseracing Act (IHA) did not apply to both foreign and domestic service suppliers of remote betting services for horse racing. Specifically, the Appellate Body reasoned that the U.S. could not justify why it permitted local companies to offer remote gambling while the U.S. prohibited Antiguan companies from offering the same type of gambling services. As a result, the U.S. failed to show that its measures did not constitute "arbitrary and unjustifiable discrimination," following the stipulation of the chapeau of Article XIV (US - Gambling Case, 2004).

In EC - Seal Products, both the Panel, analyzing the TBT agreement, classified that the EU Seal Regime was a discriminatory measure because it was designed to benefit seal products harvested by Greenland's Inuit communities over Canadian Inuit communities from the way this measure is applied. Specifically, the EU Seal Regime permits the sale of 
seal products if those products are: (i) Came from hunts undertaken by indigenous groups; (ii) Came from hunts that were carried out for the sustainable management of marine resources; or (iii) Personally imported into the EU by tourists. In its final report, the Appellate Body confirmed that the EU Seal Regime detrimentally affects the conditions of competition for Canadian and Norwegian seal products when compared to Greenlandic seal products. The AB further upheld the Panel's conclusion that although EU could provisionally justify its Seal Regime on public moral grounds, it did not meet the structures of the chapeau in GATT Article XX (EC - Seal Products Case, 2014).

\section{Moving Forward: Public Morals Exception and Its Application to Indonesia a. Indonesia's Prohibition Would Be Designed to Protect Public Morals}

Lesson from the previous WTO cases, if Indonesia intends to pass legislation that prohibits cross-border gambling on the basis of public morals, it must expressly cover specific concerns related to money laundering and underage gambling from the academic draft in which those concerns laid out by the appellate body in the WTO cases. It is because instead of legislative history or congressional report, (such as US -Gambling) the establishment of laws in Indonesia must be formally initiated through the establishment of academic draft (Law Number 12 of 2011). This draft would comprehensively explain the reason, the fact, and the objective that encourage the formulation of specific laws in Indonesia, which also covers ideological, political, cultural, social, and economic consideration.

By addressing specific concerns related to money laundering and underage gambling in academic draft, it can prove that the purpose and objective for prohibiting cross-border gambling services are to protect the interest of Indonesian society from the dire consequences of these services. As a result, this prohibition would be justified because it is designed to protect public morals.

\section{b. Indonesia's Prohibition Would be Necessary to Protect Public Morals}

Any potential legislation regulating cross-border gambling would have to be "necessary" to protect public morals, satisfying the three balancing test factors laid out by the WTO cases including the importance of societal interest; the contribution of prohibition 
to tackle the dire consequences of cross-border gambling; and the trade impact for complaining party.

For the first elements, similar to the U.S., Indonesia's prohibition would protect the common interest of Indonesian society. Moreover, if the U.S. presented the protection against the threat of money laundering and other harmful effects, Indonesia could also show if the protectionis not only against the destructive impact but also from the existence of cross-border gambling itself. In particular, it is unmistakable that gambling contradicts with prevailing religious, social, and cultural values of Indonesian society. Almost all religion in Indonesia has prohibited gambling. Specifically, Muslims consider people who gambled as immoral. Therefore, the societal interest that needs to be protected in Indonesia would be more vital and important than the societal interest of the U.S.

Equally important, for the contribution of prohibitions to tackle any destructive impact of cross-border gambling, similar to the U.S., Indonesia's prohibition would contribute significantly to tackle the harmful effects of cross-border gambling. It is because Indonesia can show how the sufficient "nexus" between cross-border gambling, money laundering, and underage gambling. Particularly, due to their methods of payments, these services are an effective mode for committing money laundering in Indonesia, and how it has affected underage gambling. This measure will not like China when it failed to provide what has been classified as sufficient "nexus" between the present of state-owned enterprise and the content review of imported products.

The third factor is the impact of the measure on international trade. The prohibition on cross-border gambling in Indonesia would significantly affect the European Union as major suppliers of these services. Nonetheless, the lesson from the US - Gambling, those rules were balancing test factor that it was not necessarily an exclusive list, and not all factors must be proven. Moreover, the judicial body could apply its discretion to determine what the strongest factor was. In the US - Gambling, the Appellate Body held that the importance of societal interest and the significant contribution of prohibition were more crucial and vital than the trade impact.

Once Indonesia could satisfy the assessment of three balancing test factors, then the judicial body would check "reasonably available alternative measures" for Indonesia. The 
lesson from the US - Gambling case, instead of prohibition, some major suppliers of crossborder gambling in Indonesia may propose trade restriction or similar to "controlled use" in Korea - Beef case or labeling systems in EC - Seal Products. This alternative measure can be analyzed through three conjunctive criteria that were established by the Appellate Body in the US - Gambling case including the following: the alternative measures must be less restrictive, it must provide outcome as effective as prohibitions, and it must be reasonably available for the U.S

Firstly, a restriction can be less trade restrictive than the prohibition because it still allows the operation of cross-border gambling in Indonesia. However, the trade restriction would not satisfy two others criteria. The second criteria require a trade restriction to preserve the right of Indonesia to achieve its level of protection as effective as prohibition. In this context, restriction means legalization of cross-border gambling in Indonesia. Then, Indonesia would need to enact a new law and policy that permit cross-border gambling in Indonesia. Once it enacts, the legalization of cross-border gambling could incur a public debate because this process would not incorporate local value or indigenous element. Therefore, the restriction would not provide an outcome as effective as a prohibition.

Finally, the third factor requires a trade restriction must be reasonably available, meaning it must create Indonesia capable of undertaking (not just theoretical in nature), and it must not be unduly burdensome such as prohibitive costs or substantial technical difficulties. In this context, Indonesia would not be capable if it just restricts instead of prohibits gambling. From the historical perspective, Indonesia had experienced to legalize gambling. Particularly, from 1966 to 1974, the casino was legalized to support the development. Next, from 1985 to 1987, soccer lottery tickets were also legalized. However, all those policies eventually were annulled because of the involvement of minors and increasing rate of crime. Moreover, due to the fact with the lack of law enforcement in Indonesia, the restriction of cross-border gambling would create technical difficulties, especially related to what fair criteria to restrict the operation of cross-border gambling in Indonesia, who control these services, how to distinguish legal and illegal cross-border gambling, how to prevent the involvement of minors, and where these services are legally available. This is pretty similar to labeling systems in EC - Seal Products wherein the EU 
would be difficult to establish systems that distinguish seal products harvested through a human hunt.

To sum up, Indonesia's prohibition would be "necessary to protect public morals" within the meaning of Article XIV GATS, Despite the fact that the prohibition would incur significant trade impact, it serves the societal interest in the highest degree and provides a significant contribution for Indonesia to tackle the harmful effects of cross-border gambling. Moreover, there is no "reasonably available alternative measure" for Indonesia except the prohibition on cross-border gambling.

\section{c. Indonesia's Prohibition Would Equally Apply to Both Foreign and Local Suppliers}

Unlike the U.S. that allowed local suppliers to provide online gambling services while prohibiting foreign suppliers from the same, or unlike China that excluded foreigninvested enterprises from importing certain cultural products, Indonesia's prohibition would apply to local and foreign suppliers alike. This likelihood of this equal application is particularly evident because Indonesia already prohibits this gambling domestically, gambling services that would have been offered by Indonesian entities. Specifically, Indonesia could show the tireless effort of The Financial Transaction Reports and Analysis Centre to block several accounts held at four banks, whose funds are allegedly linked to local online gambling websites in Indonesia. Equally important, the Ministry of Information and Technology has tried to block local online gambling websites.

Indonesian Police has also seized some agents of cross-border gambling for committing money laundering. These agents operated in many cities in Indonesia including Jakarta, Bandung, and Batam. Although those efforts have not been effective yet, Indonesian polices have continuously embattled local suppliers of online gambling. Therefore, Indonesia's prohibition would not be in the level of "arbitrary or unjustifiable discrimination" under introductory paragraph Article XIV GATS.

\section{E. CONCLUSION}

From the existing WTO provision that governs public morals exception, and how the judicial body considered public morals in the judgment of some WTO cases, Indonesia has a justification to impose public morals exception under the WTO to prohibit cross-border 
gambling services within its territory. It is because the purpose and objective for prohibiting cross-border gambling services would protect the interest of Indonesian society so that the prohibition would be designed to protect public morals. Furthermore, it would be necessary to protect public morals because it would serve societal interest in the highest degree; it would provide a significant contribution for Indonesia to tackle the harmful effects of cross-border gambling; and there is no "reasonably available alternative measure" for Indonesia except the prohibition on cross-border gambling. Finally, due to the fact that Indonesia has prohibited internet gambling services that are provided by Indonesian entities, the prohibition would equally apply to both foreign and local suppliers in crossborder gambling services in Indonesia.

\section{BIBLIOGRAPHY}

\section{Legal Documents:}

International Treaty

Vienna Convention on the Law of Treaties, opened for signature May 23, 1969, 1155 U.N.T.S. 331, 8 I.L.M. 679.

\section{United Nations Material}

United Nations Conference on Trade and Employment, Nov. 21, 1947-Mar. 24, 1948, Final Act and Related Documents, U.N. Doc. E/Conf./2/78 (Apr. 1948).

\section{World Trade Organization Materials:}

\section{WTO Panel and Appellate Body Materials}

Appellate Body Report, United States - Standards for Reformulated and Conventional Gasoline, WT/DS2/AB/R (April 29, 1996).

Appellate Body Report, Japan - Taxes on Alcoholic Beverages, WT/DS8/AB/R, WT/DS10/AB/R, WT/DS11/AB/R, adopted (1 November 1, 1996).

Appellate Body Report, European Communities - Regime for the Importation, Sale, and Distribution of Bananas, WT/DS27/AB/R (September 25, 1997).

Appellate Body Report, United States - Import Prohibition of Certain Shrimp and Shrimp Products, WT/DS8/AB/R, WT/DS10/AB/R, WT/DS11/AB/R (October 12, 1998). 
Appellate Body Report, Korea - Measures Affecting Imports of Fresh, Chilled and Frozen Beef, WT/DS161/AB/R (January 10, 2001).

Appellate Body Report, European Communities - Measures Affecting Asbestos and Asbestos-Containing Products, P 172, WT/ DS135/AB/R (March 12, 2001).

Appellate Body Report, United States - Measures Affecting the Cross-Border Supply of Gambling and Betting Services, WT/ DS285/AB/R (April 7, 2005).

Appellate Body Report, European Communities - Custom Classification of Frozen Boneless Chicken Cuts, WT/DS269/AB/R (September 27, 2005).

Panel Report, United States - Standards for Reformulated and Conventional Gasoline, WT/DS2/R (January 29, 1996).

Panel Report, United States - Measures Affecting the Cross-Border Supply of Gambling and Betting Services, WT/DS285/R (November 10, 2004).

Panel Report, China - Measures Affecting Trading Rights and Distribution Services for Certain Publications and Audio-visual Entertainment Products, WT/DS363/R (August 12, 2009).

\section{Reports:}

WTO Secretariat, Report of the WTO Secretariat on the Trade Policy Review of Haiti, WT/TPR/S/99/Rev.1 (October 7, 2003).

WTO Secretariat, Report of the WTO Secretariat on the Trade Policy Review of South Korea, WT/TPR/S/137 (August 18, 2004).

WTO Secretariat, Report of the WTO Secretariat on the Trade Policy Review of Mozambique, WT/TPR/S/79 (December 21, 2000).

WTO Secretariat, Report of the WTO Secretariat on the Trade Policy Review of Taiwan, WT/TPR/S/165Rev.1 (October 10, 2006).

World Trade Organization Guidelines for the Scheduling of Specific Commitments under the GATS, Document No: S/L/92 (March 28, 2001).

The Schedule of Specific Commitments of Indonesia in the GATS. Document GATS/SC/43 (April 15, 1994).

United States, First Written Submission From the parties, Annex A-2 WT/DS285/RW (October 16, 2006). 
U.S. Dep't of State, Publ. N Number 2411, Proposals for the Expansion of World Trade and Employment (1945).

\section{Founding Agreements:}

World Trade Organization, the Legal Texts-The Results of the Uruguay Round of Multilateral Trade Negotiations IV (Cambridge University Press 2002).

General Agreement on Tariffs and Trade art. XX (a), October 30, 1947, 61 Stat. A-11, 55 U.N.T.S. 194.

General Agreement on Trade in Services art. XIV, April 15, 1994, Marrakesh Agreement Establishing the World Trade Organization, Annex 1B, Legal Instruments - Results of the Uruguay Round, 33 I.L.M. 1177.

Marrakesh Agreement Establishing the World Trade Organization, April 15, 1994, 1867 U.N.T.S.154.

Annex 2 Agreement Establishing the World Trade Organization, Understanding on Rules and Procedures Governing the Settlement of Disputes, (April 15, 1994).

\section{Books:}

Guzman, Andrew T. and Pauwelyn Joost, 2012, International Trade Law, Wolters Kluwer: South Holland.

Van den Bossche, Peter, 2010, the Law and Policy of the World Trade Organization, ,Cambridge University Press: Cambridge.

\section{Journals:}

Andrle, John D., “A Winning Hand: A Proposal for an International Regulatory Schema With Respect to the Growing Online Gambling Dilemma in the United States", Vanderbilt Journal of Transnational Law 375 VAND. J. OF TRANSNAT'L L. 1389, 2004.

Andina, Elga, "Studi Dampak Negatif Facebook Terhadap Remaja Indonesia [A Study of Negative Impact of Facebook for Indonesian Teenagers]", 1(1) Aspirasi Jurnal 124, 2010

Charnovitz, Steve, "The Moral Exception in Trade Policy", Virginia Journal of International Law 38:4 VA J INT'L L 689, 1998. 
Gonzalez, Miguel A., "Note, Trade and Morality: Preserving Public Morals Without Sacrificing the Global Economy", Vanderbilt Journal of Transnational Law 39 VAND. J. TRANSNAT'L L 939, 2006.

L.D, Moodie, Detective Inspector, Ontario Illegal Gaming Enforcement Unit, Gambling Law Enforcement Systems Issues Conference 18, 8 March 2002.

LaPlante D.A, et al, "Sitting at the Virtual Poker Table: A Prospective Epidemiological Study of Actual Internet Poker Gambling Behavior", 25 Computers in Human Behavior 729, 2009.

Weinberg, Joel, "Everyone's A Winner: Regulating, Not Prohibiting, Internet Gambling", Southwestern University Law Review 35 Sw. U.L.REV. 293, 2006.

Wu, Mark, "Free Trade and the Protection of Public Morals: An Analysis of the Newly Emerging Public Morals Clause Doctrine", Yale Journal of International Law 33 YALE J. INT'L L. 215,2008.

\section{Websites:}

U.S. Gen. Accounting Office, Internet Gambling: An Overview of the Issues, GAO-03-89, at 3 (2002), available at http:// www.gao.gov/new.items/d0389.pdf. [accessed on January 17, 2018).

PPATK Blokir 119 Rekening Penipuan dan Judi Online [PPATK blocked 119 Account that Associated with Fraud and Online Gambling], Kompas, January 3, 2014 http://nasional.kompas.com/read/2014/01/03/1812488/PPATK.Blokir.119.Rekening. Penipuan.dan.Judi.Online. [accessed on December 3, 2017].

Iseng-iseng berujung Ketagihan [From Hobbies until Addicted], Riau Post, January 26, 2014. http://www.riaupos.co/41792-berita-awal-iseng-iseng,-berujungketagihan.html. [Accessed on December 21, 2017].

Pak Polisi Tolong Berantas Judi Online di Internet [Please Eradicate Online Gambling in Internet], Kompas, April 19, 2013. http://teknologi.kompasiana.com/internet/2013/04/19/pak-polisi-tolong-berantas-judionline-di-internet--548152.htm. [accessed on November 14, 2017). 